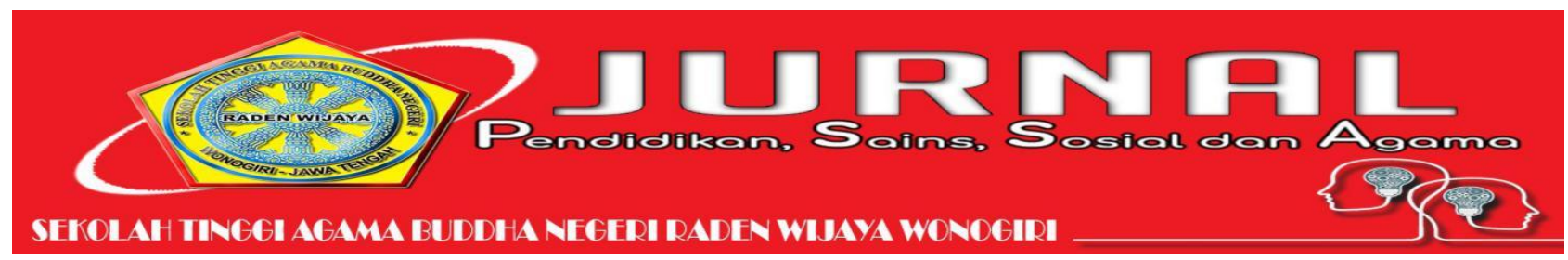

\title{
PEMANFAATAN APLIKASI WHATSAPP SELAMA PANDEMI COVID-19 SEBAGAI SARANA DISKUSI PADA MAHASISWA PENDIDIKAN MATEMATIKA
}

\author{
Nuraini*, Afif Afghohani, Annisa Prima Exacta \\ Universitas Veteran Bangun Nusantara Sukoharjo \\ ininura54@gmail.com
}

\begin{abstract}
Abstrak
Penelitian ini bertujuan untuk mengetahui respons mahasiswa terhadap pemanfaatan aplikasi Whatsapp sebagai sarana diskusi pembelajaran selama pandemi Covid-19. Metode yang digunakan dalam penelitian ini adalah deskriptif kualitatif. Data dalam penelitian ini diperoleh dari hasil pengisian angket dan wawancara. Sumber data dalam penelitian ini adalah subjek dari mana data diperoleh, yaitu mahasiswa semester 6 pendidikan matematika Universitas Veteran Bangun Nusantara Sukoharjo. Teknik analisis data yang digunakan adalah reduksi data, penyajian data dan penarikan kesimpulan. Hasil analisis angket menunjukkan bahwa persentase rata-rata respons mahasiswa terhadap pemanfaatan aplikasi WhatsApp sebagai sarana diskusi pembelajaran berada pada kategori positif. Sedangkan berdasarkan analisis hasil wawancara, mahasiswa juga memberikan respons yang positif terhadap pemanfaatan aplikasi WhatsApp sebagai sarana diskusi pembelajaran. Pada penelitian ini pemeriksaan keabsahan data menggunakan teknik triangulasi metode, yaitu dengan membandingkan hasil penelitian dengan hasil wawancara. Berdasarkan perbandingan analisis data dengan angket dan wawancara, dapat disimpulkan bahwa respons mahasiswa dalam pemanfaatan aplikasi WhatsApp sebagai sarana diskusi berada pada kategori positif
\end{abstract}

Kata Kunci: WhatsApp, Sarana diskusi, Matematika, Pandemi Covid-19

\begin{abstract}
This study aims to determine students respond to the use of the Whatsapp application as a means of learning discussion during the Covid-19 pandemic. The method used in this research is descriptive qualitative. The data in this study were obtained from the results of filling out questionnaires and interviews. Sources of data in this study were the subjects from which the data were obtained, namely 6th semester students of mathematics education at Universitas Veteran Bangun Nusantara Sukoharjo. The data analysis technique used was data reduction, data presentation and conclusion drawing. The results of the questionnaire analysis show that the average percentage of student responses to the use of the WhatsApp application as a means of learning discussion is in the positive category. Meanwhile, based on the analysis of the interview results, students also gave positive responses to the use of the WhatsApp application as a means of learning discussion. In this study, checking the validity of the data used triangulation techniques, namely by comparing the results of the study with the results of interviews. Based on the comparison of data analysis with questionnaires and interviews, it can be concluded that the student responses in using the WhatsApp application as a means of discussion are in the positive category.
\end{abstract}

Key Word: WhatsApp; Response; Means of discussion, Covid-19 Pandemic 


\section{PENDAHULUAN}

Tahun 2020 hampir seluruh belahan di dunia sedang dilanda wabah virus corona (Covid-19) tak terkecuali Indonesia. WHO (World Health Organization) telah menyatakan wabah tersebut sebagai pandemi global. Penyebaran Covid-19 memberikan dampak yang luar biasa baik kepada negara maupun masyarakat. Dalam bidang pendidikan, dampaknya sangat terasa terutama setelah pemerintah memberlakukan aturan untuk belajar, bekerja, dan beribadah di rumah, hal ini berdasarkan SE Mendikbud Nomor 36962/MPK.A/HK/2020 perihal Pembelajaran secara Daring dan Bekerja dari Rumah dalam Rangka Pencegahan Penyebaran Corona Virus Disesase (Covid19).

Setelah adanya surat edaran tersebut, Universitas Veteran Bangun Nusantara Sukoharjo juga menerapkan pembelajaran secara online. Berdasarkan hasil wawancara kepada mahasiswa semester 2, 4 dan 6 pelaksanaan kuliah on-line dilaksanakan melalui aplikasi WhatsApp, SPADA, Google Classroom,dan Zoom. Salah satu aplikasi yang paling sering digunakan oleh mahasiswa pendidikan matematika dalam pelaksanaan pembelajaran on-line adalah WhatsApp.

Menurut Suryadi (2018) WhatsApp Messenger itu sendiri merupakan aplikasi pesan lintas platform yang memungkinkan seseorang bertukar informasi tanpa biaya SMS. Aplikasi WhatsApp dapat digunakan untuk bertukar informasi berupa gambar maupun pesan, sehingga sangat memungkinkan jika harus melakukan diskusi melalui WhatsApp.

Menurut Yudi (2012) sarana berarti alat langsung untuk mencapai tujuan pendidikan. Menurut Ermi (2015) diskusi merupakan suatu metode pembelajaran yang di dalamnya terdapat percakapan antara individu dengan indvidu lainnya yang terbentuk ke dalam wadah atau kelompok yang dihadapkan oleh suatu permasalahan sehingga mereka dapat bertukar pikiran untuk mendapatkan pemecahan masalah yang benar melalui kesepakatan bersama. Berdasarkan pengertian tersebut dapat disimpulkan bahwa sarana diskusi adalah alat yang di gunakan dalam proses pembelajaran yang berguna untuk bertukar pikiran antara individu dengan individu lainnya dalam menyelesaikan suatu permasalahan.

Berdasarkan uraian tersebut maka, penelitian perlu dilakukan untuk mengetahui Pemanfaatan Aplikasi WhatsApp Selama Pandemi Covid-19 Sebagai Sarana Diskusi Pembelajaran Pada Mahasiswa Pendidikan Matematika Universitas Veteran Bangun Nusantara Sukoharjo.

\section{METODE}

Penelitian ini merupakan jenis penelitian deskriptif kualitatif. Menurut Moleong (2017:6), penelitian kualitatif adalah penelitian yang bermaksud untuk memahami fenomena tentang yang dialami oleh subyek penelitian misalnya perilaku, persepsi, motivasi, tindakan, dll., secara hilostik, dan dengan cara deskripsi dalam bentuk kata-kata dan bahasa, pada suatu konteks khusus yang alamiah dan dengan memanfaatkan berbagai metode ilmiah. Menurut Arikunto (2013:36), penelitian deskriptif pada umumnya hanya memaparkan saja gambaran yang terjadi pada fenomena, yang dalam hal ini kegiatan yang diteliti, kemudian diambil kesimpulan.

Penelitian ini dilakukan pada tanggal 13 Juli 2020 dengan subjek penelitian mahasiswa semester 6 pendidikan matematika Universitas Veteran Bangun Nusantara Sukoharjo. Data dalam penelitian ini diperoleh dari hasil pengisian angket dan juga wawancara. Angket ditujukan kepada mahasiswa semester 6 pendidikan matematika yang berguna untuk mengetahui respons mahasiswa mengenai pemanfaatan aplikasi WhatsApp sebagai sarana diskusi.

Tabel 1. Indikator Respons Mahasiswa

\begin{tabular}{ll}
\hline Indikator & Kategori \\
\hline 1. Mahasiswa sering & Sangat \\
menggunakan WA & Positif \\
2. Mahasiswa mendapat & \\
& kepuasan dalam \\
& pembelajaran \\
& menggunakan WA \\
3. Mahasiswa mendapat & \\
& kemudahan belajar dengan \\
& menggunakan WA \\
\hline
\end{tabular}


4. Mahasiswa dapat

berkomunikasi dan

bertukar informasi melalui

WA

(Elianur: 2017)

$\begin{array}{ll}\begin{array}{l}\text { Memenuhi } 3 \text { dari } 4 \\ \text { indikator respons } \\ \text { mahasiswa }\end{array} & \text { Positif } \\ \begin{array}{l}\text { Memenuhi } 2 \text { dari } 4 \\ \text { indikator respons } \\ \text { mahasiswa }\end{array} & \begin{array}{l}\text { Kurang } \\ \text { Positif }\end{array} \\ \begin{array}{l}\text { Memenuhi } 1 \text { dari } 4 \\ \text { indikator atau tidak } \\ \text { memenuhi semua }\end{array} & \text { Tidak } \\ \text { indikator respons } \\ \text { mahasiswa }\end{array}$

Persentase respons mahasiswa dapat dihitung dengan menggunakan rumus:

Persentase $=\frac{\text { Jumlah Skor Responden }}{\text { Skor Ideal }} \times 100 \%$

Sumber: Rusydi (2018)

Kategori persentase respons mahasiswa:

$\mathrm{NRS} \geq 85 \% \quad=$ sangat positif

$70 \% \leq \mathrm{NRS}<85 \%=$ positif

$50 \% \leq \mathrm{NRS}<70 \%=$ kurang positif

NRS $<50 \%=$ tidak positif

Sumber: Khabibah (dalam Yamasari: 2010)

Setelah menghitung respons tiap mahasiswa, lagkah selanjutnya adalah menentukan subjek untuk wawancara yaitu jika presentase respons mahasiswa termasuk kedalam kategori sangat positif, namun pada indikator hanya memenuhi beberapa saja, maka mahasiswa tersebut termasuk kedalam kategori sangat positif, dan mahasiswa tersebut dapat diteliti lebih lanjut menggunakan teknik wawancara. Hal ini juga berlaku pada nilai respons mahasiswa dengan kategori positif, kurang positif dan tidak positif.

Setelah melakukan wawancara, langkah selanjutnya adalah pemeriksaan keabsahan data. Pada penelitian ini pemeriksaan keabsahan data menggunakan teknik triangulasi metode. Triangulasi metode menurut Patton (dalam Moleong 2017: 331) terdapat dua strategi, yaitu: (1) pengecekan derajat kepercayaan penemuan hasil penelitian beberapa teknik pengumplan data dan (2) pengecekan derajat kepercayaan beberapa sumber data dengan metode yang sama.

Pada penelitian ini dapat dicapai dengan membandingkan data hasil penelitian dengan data hasil wawancara.

\section{HASIL}

Berdasarkan pengisian angket yang telah dilakukan oleh 31 mahasiswa semester 6 pendidikan matematika Universitas Veteran Bangun Nusantara Sukoharjo, berikut akan dipaparkan deskripsi hasil angket respons mahasiswa terhadap pemanfaatan aplikasi WhatssApp sebagai sarana diskusi. Berdasarkan data yang telah diolah dengan menggunakan rumus nilai respons, terdapat 9 mahasiswa memiliki respons sangat positif terhadap pemanfaatan aplikasi WhatsApp sebagai sarana diskusi. Terdapat 18 mahasiswa yang memiliki respons positif terhadap pemanfaatan aplikasi WhatsApp sebagai sarana diskusi. Terdapat 4 mahasiswa yang memiliki respons kurang positif terhadap pemanfaatan aplikasi WhatsApp sebagai sarana diskusi. Berdasarkan uraian tersebut, dapat disimpulkan bahwa respons mahasiswa terhadap pemanfaatan aplikasi WhatsApp sebagai sarana diskusi berada pada kategori positif.

Selain mengitung respons tiap mahasiswa, pada pebelitian ini juga mengitung respons mahasiswa tiap indikator. Hal ini dapat dilihat pada tabel. 2 sebagai berikut:

Tabel 2. Respons Mahasiswa Tiap Indikator

\begin{tabular}{lcc}
\hline Indikator & Persentase & Kategori \\
\hline $\begin{array}{l}\text { Mahasiswa sering } \\
\text { menggunakan }\end{array}$ & & \\
WhatsApp & & Positif \\
Mahasiswa mendapat & & \\
kepuasan dalam & & \\
pembelajaran & 73,39 & Positif \\
menggunakan & & \\
$\begin{array}{l}\text { WhatsApp } \\
\text { Mahasiswa mendapat }\end{array}$ & & \\
kemudahan belajar & & \\
dengan menggunakan & 74,40 & Positif \\
Whatsapp & & \\
\hline
\end{tabular}




Mahasiswa dapat
berkomunikasi dan
bertukar informasi
melalui WhatsApp

Pengamatan pada tabel.2 menunjukkan, Persentase respons mahasiswa pada indikator 1 (mahasiswa sering menggunakan WhatsApp) sebesar 79,03\% sehingga termasuk kedalam kategori positif. Persentase respons mahasiswa pada indikator 2 (mahasiswa mendapatkan kepuasan dalam pembelajaran menggunakan WhatsApp) sebesar $73,39 \%$ sehingga termasuk kedalam kategori positif. Persentase respons mahasiswa pada indikator 3 (mahasiswa mendapat kemudahan belajar dengan menggunakan WhatsApp) sebesar 74,40\% sehingga termasuk kedalam kategori positif. Persentase respons mahasiswa pada indikator 4 (mahasiswa dapat berkomunikasi dan bertukar informasi melalui WhatsApp) sebesar $82,53 \%$ sehingga termasuk kedalam kategori positif.

Setelah menghitung nilai respons mahasiswa, langkah selanjutnya adalah wawancara, wawancara dilakukan untuk pengumpulan data dan pengecekan keabsahan data. Subjek yang akan diwawancara ditentukan dari kategori respons mahasiswa, yang mana jika mahasiswa tersebut memiliki persentase respons yang termasuk kedalam kategori sangat positif, namun tidak memenuhi indikator respons sangat positif. $\mathrm{Ha}$ ini juga berlaku pada kategori positif, kurang positif dan tidak positif.

Dalam penelitian ini, terdapat mahasiswa yang persentase responnya termasuk kategori positif, namun memenuhi 4 indikator. Berikut adalah mahasiswa yang termasuk kedalam kategori positif, namun tidak memenuhi indikator posiif:

Tabel.3 Kategori Respons Positif

\begin{tabular}{ccll}
\hline Inisial Nama & $\begin{array}{l}\text { Kategor } \\
\text { i }\end{array}$ & Keterangan & \\
\hline 1. TH & Positif & $\begin{array}{l}\text { Memenuhi } \\
\text { indikator }\end{array}$ & 4 \\
2. DAP & Positif & $\begin{array}{l}\text { Memenuhi } \\
\text { indikator }\end{array}$ & 4 \\
3. AKR & Positif & $\begin{array}{l}\text { Memenuhi } \\
\text { indikator }\end{array}$ & 4 \\
\hline
\end{tabular}

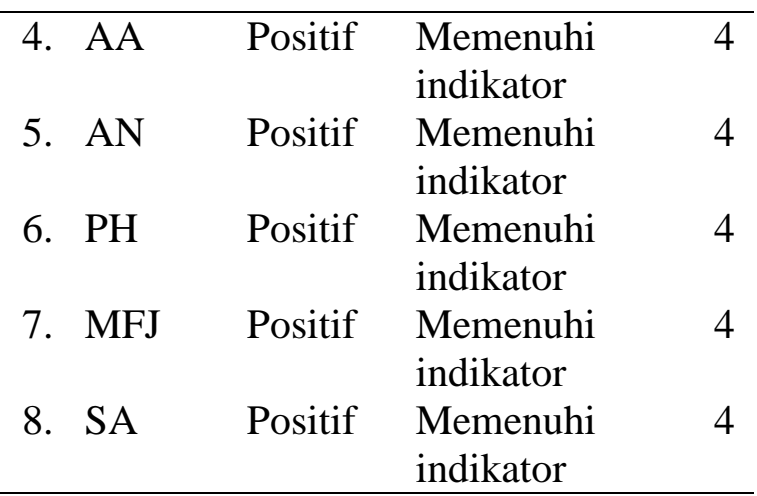

Dari pengamatan pada tabel.3 diketahui bahwa 8 mahasiswa tersebut memberikan respons yang berada pada kategori positif. Syarat pada kategori positif adalah jika memenuhi 3 indikator, sedangkan 8 mahasiswa tersebut memenuhi 4 indikator, disini peneliti memberikan sebutan baru untuk menentukan kategorinya, yaitu ke-delapan mahasiswa tersebut berada pada kategori melampaui positif. Sehingga salah satu mahasiswa yang berada pada kategori melampaui positif dapat dijadikan subjek untuk wawancara.

Tabel. 4 Kategori Respons Positif

\begin{tabular}{clll}
\hline $\begin{array}{c}\text { Inisial } \\
\text { Nama }\end{array}$ & $\begin{array}{l}\text { Kategor } \\
\text { i }\end{array}$ & Keterangan & \\
\hline 1. SF & Positif & $\begin{array}{l}\text { Memenuhi } \\
\text { indikator }\end{array}$ & 2 \\
2. DAP & Positif & $\begin{array}{l}\text { Memnuhi } \\
\text { indikator }\end{array}$ & 2 \\
\hline
\end{tabular}

Dari pengamatan pada tabel 4 diketahui bahwa 2 mahasiswa tersebut memberikan respons yang berada pada kategori positif. Syarat pada kategori positif adalah jika memenuhi 3 indikator, sedangkan 8 mahasiswa tersebut memenuhi 2 indikator, disini peneliti memberikan sebutan baru untuk menentukan kategorinya, yaitu kedua mahasiswa tersebut berada pada kategori menuju positif. Sehingga salah satu mahasiswa yang berada pada kategori menuju positif dapat dijadikan subjek untuk wawancara.

Tabel. 5 Kategori Respons Kurang Positif

\begin{tabular}{clll}
\hline $\begin{array}{c}\text { Inisial } \\
\text { Nama }\end{array}$ & $\begin{array}{l}\text { Kategor } \\
\mathbf{i}\end{array}$ & \multicolumn{2}{l}{ Keterangan } \\
\hline 1. SK & Kurang & Tidak & memenuhi \\
\hline
\end{tabular}




\section{Positif indikator}

Dari pengamatan pada tabel 5 diketahui bahwa mahasiswa tersebut memberikan respons yang berada pada kategori kurang positif. Syarat pada kategori kurang positif adalah jika memenuhi 2 indikator, sedangkan mahasiswa tersebut tidak memenuhi indikator, disini peneliti memberikan sebutan baru untuk menentukan kategorinya, yaitu mahasiswa tersebut berada pada kategori menuju kurang positif. Sehingga mahasiswa yang berada pada kategori menuju kurang positif dapat dijadikan subjek untuk wawancara.

Tabel. 6 Kategori Respons Kurang Positif

\begin{tabular}{|c|c|c|c|}
\hline $\begin{array}{l}\text { Inisial } \\
\text { Nama }\end{array}$ & $\begin{array}{l}\text { Kategor } \\
\text { i }\end{array}$ & Keterangan & \\
\hline 1. AJP & $\begin{array}{l}\text { Kurang } \\
\text { Positif }\end{array}$ & $\begin{array}{l}\text { Memenuhi } \\
\text { indikator }\end{array}$ & 1 \\
\hline 2. $\mathrm{TE}$ & $\begin{array}{l}\text { Kurang } \\
\text { Positif }\end{array}$ & $\begin{array}{l}\text { Memenuhi } \\
\text { indikator }\end{array}$ & 1 \\
\hline
\end{tabular}

Dari pengamatan pada tabel 4.14 diketahui bahwa kedua mahasiswa tersebut memberikan respons yang berada pada kategori kurang positif. Syarat pada kategori kurang positif adalah jika memenuhi 2 indikator, sedangkan mahasiswa tersebut hanya memenuhi 1 indikator, disini peneliti memberikan sebutan baru untuk menentukan kategorinya, yaitu mahasiswa tersebut berada pada kategori menuju kurang positif. Sehingga mahasiswa yang berada pada kategori menuju kurang positif dapat dijadikan subjek untuk wawancara.

Berdasarkan uraian diatas diperoleh subjek untuk wawancara adalah salah satu mahasiswa yang berada pada kategori sangat positif, menuju positif, melampaui positif dan menuju kurang positif.

Berdasarkan hasil wawancara kepada 5 mahasiswa, diketahui bahwa Pada pertanyaan soal nomor satu, rata-rata jawaban mahasiswa adalah sering menggunakan WhatsApp terutama untuk pembelajaran. Sehingga dapat disimpulkan bahwa pertanyaan mengenai intensitas penggunaan WhatsApp mendapatkan respons yang sangat positif. Pada pertanyaan nomor dua, tiga mahasiswa menjawab cukup membantu dan mendukung pembelajaran. Sedangkan dua mahasiswa lainnya menjawab tidak. Sehingga dapat disimpulkan bahwa, penggunaan aplikasi WhatsApp sebagai sarana diskusi memberikan respons yang positif. Pada pertanyaan nomor tiga, empat mahasiswa menjawab iya dan satu mahasiswa menjawab tidak. Sehingga dapat disimpulkan bahwa, mahasiswa mendapatlan kemudahan dalam belajar dengan menggunakan WhatsApp. Pada pertanyaan nomor empat, satu mahasiswa menjawab iya, dua mahasiswa menjawab lumayan puas, satu mahasiswa menjawab kurang puas, dan satu mahasiswa lainnya menjawab belum puas. Sehingga dapat disimpulkan bahwa, rata-rata mahasiwa mendapatkan kepuasan dalam penggunaan WhatsApp sebagai sarana diskusi. Pada pertanyaan nomor lima. Tiga mahasiswa menjawab iya. Satu mahasiswa menjawab beberapa terpenuhi, dan satu lainnya menjawab tidak. Sehingga dapat disimpulkan bahwa, kebutuhan informasi dengan menggunakan WhatsApp terpenuhi

Berdasarkan paparan hasil wawancara tersebut, dapat disimpulkan bahwa pemanfaatan aplikasi WhatsApp sebagai sarana diskusi mendapatkan respons yang positif dari mahasiswa.

Berdasarkan hasil perbandingan analisis angket respons mahasiswa dan hasil wawancara dapat disimpulkan bahwa, ratarata respons mahasiswa terhadap pemanfaatan aplikasi WhatsApp sebagai sarana diskusi, berada pada kategori positif. Sedangkan berdasarkan hasil wawancara, dapat disimpulkan bahwa rata-rata mahasiswa memberikan respons yang positif terhadap pemanfaatan aplikasi WhatsApp sebagai sarana diskusi. Perbandingan dari hasil pengisian angket dan juga hasil wawancara menunjukkan bahwa, respons mahasiswa terhadap pemanfaatan aplikasi WhatsApp sebagai sarana diskusi berada pada kategori positif.

Hasil penelitian menunjukkan bahwa respons mahasiswa berada pada kategori positif, itu berarti penggunaan aplikasi WhatsApp baik digunakan dalam proses pembelajaran online. Hal ini relevan dengan penelitian yang 
telah dilakukan oleh Khusaini (2017) mengenai pengoptimalan penggunaan WA yang menunjukkan beberapa peran positif dalam perkuliahan Penilaian Pendidikan Fisika. Penggunaan WA dalam perkuliahan dapat membantu mahasiswa berdiskusi dengan sesamanya maupun dengan dosen pengampu perkuliahan.

\section{KESIMPULAN}

Bedasarkan hasil penelitian dan pembahasan yang telah diuraikan, dapat disimpulkan bahwa persentase respons mahasiswa terhadap pemanfaatan aplikasi WhatsApp sebagai sarana diskusi sebesar $78,56 \%$ sehingga respons mahasiswa berada pada kategori positif.

\section{Daftar Pustaka}

Arikunto, Suharsimi. 2013. Prosedur Penelitian Suatu Pendekatan Praktik. Jakarta:PT Rineka Cipta

Elianur, Carona. Pemanfaatan Aplikasi WhatsApp Sebagai Sarana Diskusi Antara Pengawas Dan Guru Pendidikan Agama Islam. Jurnal AsSalam. Vol.1(2). 2017. 1-14.

Ermi, Netti. Penggunaan Metode Diskusi Belajar Untuk Meningkatkan Hasil Belajar Materi Perubahan Sosial Pada Siswa Kelas XII SMA Negeri 4 Pekanbaru. Jurnal Sorot. Volume 10, Nomor 2. 2015.

Khusaini. Optimalisasi Penggunaan WhatsApp dalam Perkuliahan Penilaian Pendidikan Matematika. Jurnal Riset dan Kajian Pendidikan Fisika.Vol.4 No.1. 2017.

Moleong, Lexy J. 2017. Metodologi Penelitian Kualitatif. Bandung: PT. Remaja Rosdakarya Offset

Rusydi, Ibrahim. Analisis Efektivitas Pemanfaatan Multimedia Pada pencitraan AMIK Amokom Cipta
Darma Surakarta. Jurna TIKomSin. ISSN: 2338-4018. 2018.

Suryadi. Penggunaan Sosial Media WhatsApp Dan Pengaruhnya Terhadap Disiplin Belajar Peserta Didik Pada Mata Pelajaran Pendidikan Agama Islam.Edukasi Islam, Jurnal Pendidikan Islam. Vol.07, No.1 2018.

Yudi, Alex Aldha.Pengembangan Mutu Pendidikan Ditinjau Dari Segi Sarana Dan Prasana (Sarana Dan Prasarana PPLP).Cerdas Sifa Pendidikan. Vol.1 No.1 2012.

Yamasari, Yuni. Pengembangan Media Pembelajaran Matematika Berbasis ICT Yang Berkualitas. Seminar Nasional Pascasarjana X-ITS. 2010. 